\title{
Climate Change Impacts on Sunflower (Helianthus annus L.) Plants
}

\author{
Eloísa Agüera *(D) and Purificación de la Haba \\ Department of Botany, Ecology and Plant Physiology, Faculty of Science, University of Córdoba, \\ 14071 Córdoba, Spain; bv1hahep@uco.es \\ * Correspondence: vg1agbue@uco.es
}

check for updates

Citation: Agüera, E.; de la Haba, P. Climate Change Impacts on Sunflower (Helianthus annus L.) Plants. Plants 2021, 10, 2646. https:/ / doi.org/10.3390/plants10122646

Academic Editors: Ignacio González Fernández, Victoria Bermejo and Vicent Calatayud

Received: 19 October 2021

Accepted: 29 November 2021

Published: 1 December 2021

Publisher's Note: MDPI stays neutral with regard to jurisdictional claims in published maps and institutional affiliations.

Copyright: (c) 2021 by the authors. Licensee MDPI, Basel, Switzerland. This article is an open access article distributed under the terms and conditions of the Creative Commons Attribution (CC BY) license (https:// creativecommons.org/licenses/by/ $4.0 /)$.

\begin{abstract}
The biochemical, biological, and morphogenetic processes of plants are affected by ongoing climate change, causing alterations in crop development, growth, and productivity. Climate change is currently producing ecosystem modifications, making it essential to study plants with an improved adaptive capacity in the face of environmental modifications. This work examines the physiological and metabolic changes taking place during the development of sunflower plants due to environmental modifications resulting from climate change: elevated concentrations of atmospheric carbon dioxide $\left(\mathrm{CO}_{2}\right)$ and increased temperatures. Variations in growth, and carbon and nitrogen metabolism, as well as their effect on the plant's oxidative state in sunflower (Helianthus annus L.) plants, are studied. An understanding of the effect of these interacting factors (elevated $\mathrm{CO}_{2}$ and elevated temperatures) on plant development and stress response is imperative to understand the impact of climate change on plant productivity.
\end{abstract}

Keywords: carbon metabolism; growth; nitrogen metabolism; oxidative state; photosynthesis

\section{Introduction}

The UN Framework Convention (1992) on Climate Change defines climate change as a type of climate modification that is attributed directly or indirectly to human activity. This modification alters the composition of the global atmosphere and acts in addition to the natural climate variability, which can be observed over comparable time periods.

During the last decades, anthropic emissions of greenhouse gases, such carbon dioxide $\left(\mathrm{CO}_{2}\right)$, nitrous oxide $\left(\mathrm{N}_{2} \mathrm{O}\right)$, and methane $\left(\mathrm{CH}_{4}\right)$ have induced alterations in natural climate cycles of the Earth, elevating the mean surface temperature of the planet [1]. The Intergovernmental Panel on Climate Change (IPCC) predicted that between 2060 and 2100, CO levels will reach concentrations of $660-790 \mu \mathrm{L} \mathrm{L}^{-1}$, while the global surface temperature will be between 2.0 and $3.7^{\circ} \mathrm{C}$ above the pre-industrial average temperature [2]. Ongoing gas emission is one of the current causes of climate change, since it leads to increased temperatures due to gas absorbing infrared radiation $[3,4]$. On the other hand, the intensive use of chemical fertilizers alters the global cycle of nitrogen, increasing the levels of $\mathrm{N}_{2} \mathrm{O}$ and NO, which also promotes global warming [5] (Figure 1).

Climate change causes major alterations in ecosystems, leading to extreme climaterelated phenomena, such as droughts, floods, heatwaves, hurricanes, etc. [2]. In general, the biochemical, biological, and morphogenetic processes of plants are affected by climate change, resulting in alterations in their development, growth, and productivity [6]. The decrease in plant performance is mainly caused by biotic and abiotic stress factors. Attaining new stress-resistant crops is a priority for both conventional and modern improvement (biotechnological). Gruissem et al. [7] suggested the importance of studying plants that are more flexible and have a greater adaptive capacity with respect to the modifications produced by climate change. 


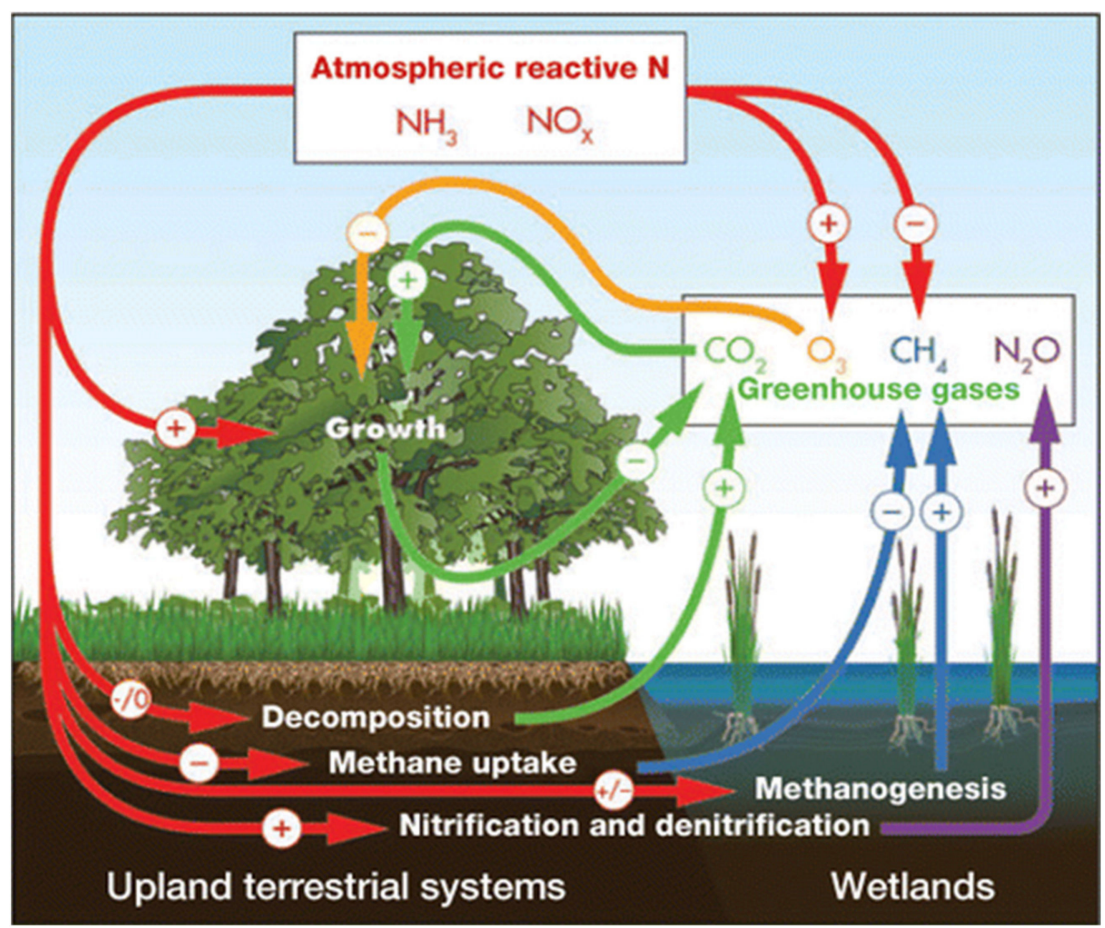

Figure 1. Gases and processes involved in the greenhouse effect. (Sources from Templer et al. 2012).

Sunflower, the fourth most important oil crop worldwide, is normally susceptible to low temperatures and salinity [8-10]. The sunflower crop is a rainfed crop, showing tolerance to water stress conditions by presenting a highly explorative root system [11-13]. Although the mechanisms involved in this tolerance remain unclear at the molecular level, an increase in the expression level of photosynthesis related genes as well as higher levels of sugars, osmoprotectant amino acids, and ionic nutrients under water stress conditions have recently been observed in sunflower plants. In addition, transcription factors have been identified that were upregulated during water stress conditions and that may act as hubs in the transcriptional network. Many of these transcription factors belong to families implicated in the water stress response in model species [14]. These findings will provide useful biotechnological tools to improve stress tolerance while maintaining crop yield under restricted water availability.

Therefore, this review focuses on the physiological and metabolic changes taking place during the development of sunflower plants due to environmental modifications resulting from climate change, especially elevated concentrations of atmospheric carbon dioxide $\left(\mathrm{CO}_{2}\right)$ and increased temperatures.

\section{Effects of Elevated $\mathrm{CO}_{2}$ and Elevated Temperatures on Sunflower Plants Growth}

In general, elevated $\mathrm{CO}_{2}$ levels, directly and indirectly affect plant growth and development, modifying numerous physiological processes. Elevated concentrations of $\mathrm{CO}_{2}$ tend to increase plant growth and produce large quantities of biomass, especially C3 plants, since they provide additional C (fertilization effect) [15]. Plant growth is determined by cell division and expansion. These processes are coordinated and controlled during organogenesis though a series of factors, including vegetable hormones, and they respond to environmental signals [16-18]. An elevated atmospheric $\mathrm{CO}_{2}$ concentration level may positively influence cell division and expansion $[19,20]$. Increased cell expansion is associated with greater extensibility of the cell wall and increased activity of the enzymes that fluidify the wall, such as xyloglucan endotransglucosylase (XET) [21]. It has been found that in soy leaves and Betula papyrifera, which are grown in a $\mathrm{CO}_{2}$-enriched environment, certain genes participating in the cell cycle (coding histones) or fluidifying the cell wall (coding expansins and XET) increase their expression [22,23]. It has been 
verified that a major supplement of carbon at elevated $\mathrm{CO}_{2}$ concentrations may contribute to accelerating cell division and expansion in meristematic tissues and improves early plant growth and development [24]. Sunflowers grown at elevated $\mathrm{CO}_{2}$ concentrations were shown to reveal improved growth, reflected in an increased specific leaf mass (SLM), which refers to the dry weight of young leaves (16 days) [25]. It is unclear whether or not this increased cell cycle activity resulting from the increased $\mathrm{CO}_{2}$ is due to the fact that the plant has more photoassimilates for growth or whether it is because of the divergence produced in gene expression in response to the increased sugar levels [26]. However, in sunflower plants grown at elevated temperatures, a reduced growth has been observed, as reflected when determining the SLM and area of the leaf as well as the soluble protein content [27]. Elevated temperatures negatively affect cell division as well as cell expansion since temperature is one of the main stresses stimulating protein degradation and causing tissue senescence or death [28,29]. Elevated $\mathrm{CO}_{2}$ stimulates the root and shoot growth of wheat, but this stimulation was found to reduce when plants were grown in combined elevated temperature and elevated $\mathrm{CO}_{2}$ [30]. Lee et al. [31] showed that while elevated temperatures may negatively influence the growth and yield of potato crops, concurrent and appropriate elevation of $\mathrm{CO}_{2}$ and temperature can promote balanced development of source and sink organs and positively affect potato productivity. Field experiments on sunflower production using an OilCROP-SUN model predicted that the increase in temperature negatively affects sunflower productivity in Pakistan. Although increased $\mathrm{CO}_{2}$ concentration showed a positive effect on sunflower, it does not fully compensate for the negative effect of increased temperature [32]. In irrigated crops, adaptation to climate change depends on the availability of water, thus the combined effects of high atmospheric $\mathrm{CO}_{2}$ and climate change decrease crop yields if agricultural management practices are not modified [33].

\section{Elevated $\mathrm{CO}_{2}$ Levels and Elevated Temperatures on Carbon Metabolism in Sunflower Plants}

Elevated levels of $\mathrm{CO}_{2}$ increase the photosynthetic rate; therefore, crop growth and productivity are increased [34]. It has been observed that an elevated concentration of $\mathrm{CO}_{2}$ stimulates the photosynthetic fixation of $\mathrm{CO}_{2}$, as well as stoma transpiration and conductance in young sunflower plant leaves [25]. Elevated levels of $\mathrm{CO}_{2}$ concentration increase the photosynthesis rate in C3 plants, since the Ribulose-1,5-bisphosphate carboxylase/oxygenase (Rubisco) enzyme involved in the fixation process of $\mathrm{CO}_{2}$ and photorespiration, is not saturated in the environmental $\mathrm{CO}_{2}$ concentration [35]. Therefore, an increase in atmospheric $\mathrm{CO}_{2}$ would increase the leaf's level of internal $\mathrm{CO}_{2}$, as well as the $\mathrm{CO}_{2} / \mathrm{O}_{2}$ ratio, affecting the Rubisco and thereby favoring the carboxylation reaction as compared with the oxygenation process. Elevated $\mathrm{CO}_{2}$ concentrations may reduce the photorespiration process in $\mathrm{C} 3$ plants and, therefore, the production of cellular hydrogen peroxide $\left(\mathrm{H}_{2} \mathrm{O}_{2}\right)$ derived from the metabolism of glycolate [36,37]. On the other hand, it has been shown that the efficiency of photosystem I and II (PSI and PSII) increases at elevated levels of $\mathrm{CO}_{2}$, producing more adenosine triphosphate (ATP) and reduced nicotinamide adenine dinucleotide phosphate (NADPH) [38,39]. In addition, increased efficiency in the use of light is observed as a result of the increased flow of electrons between the PSII and PSI under circumstances of high $\mathrm{CO}_{2}$ [40]. Vicente et al. [41] revealed an increased gene and protein expression related to light reactions of photosynthesis.

This stimulating effect of photosynthesis caused by elevated levels of $\mathrm{CO}_{2}$ may be temporary, given the acclimation of photosynthesis to elevated concentrations of $\mathrm{CO}_{2}$, which initially stimulates the fixation of $C$ but is followed by a slow decrease in the $C$ fixation process [42]. Various studies have indicated that the acclimation of photosynthesis is due to factors such as reduced content of Rubisco [43], the inhibition of the assimilation of $C$ due to the accumulation of non-structural carbohydrates that suppress the expression of genes related to photosynthesis [43,44], and a reduction in the concentration of nutrients, especially $\mathrm{N}$ in plant tissues, due to the inhibition of photoassimilates of $\mathrm{NO}_{3}{ }^{-}$[45-47]. In Populus tremuloides and B. papyrifera in the presence of elevated $\mathrm{CO}_{2}$, net photosynthesis in- 
creased by $43-73 \%$ and the hexose ratio increased when compared with that of sucrose [48]. This was also observed in sunflower leaves [25]. When cucumber plants were grown at high concentrations of $\mathrm{CO}_{2}$, an increase in the content of starch and soluble sugars was also observed in the leaf, as well as a decrease in the content of nitrogen $[49,50]$. However, the effect of the elevated $\mathrm{CO}_{2}$ on the accumulation of hexose varied between species [51,52], as did the sensitivity of the distinct plant tissues [53].

The plant growth and yield depend upon the species specific temperature optimum [54]. An elevated temperature conditions the rate of enzymatic reactions and modifies the structure and activity of macromolecules [55]. In addition, it is known that elevated temperatures modify the composition and structure of cell membranes, increasing the fluidity of membrane lipids and decreasing electrostatic interactions between polar groups of the proteins within the aqueous phase of the membrane and producing a loss of ions [56]. Therefore, photosynthesis at elevated temperatures is modified, since the thylakoid membrane is altered along with the thylakoid shape and arrangement [57]. On the other hand, high temperatures also cause photoinhibition of the PSII through the effect on the oxygen emitter complex, which is destroyed by heat [58-60]. The decreased photosynthetic rate may also be due to the fact that elevated temperatures cause stomatal closure to prevent water loss, resulting in a decreased exchange of gases between the leaf and the atmosphere [61]. De la Mata et al. [27], attributed the lower net photosynthesis to elevated temperatures in primary sunflower leaves, compared with a control group, causing a reduction in photosynthetic pigments and partial stomatal closure. Greer and Weedon [62] observed that the average rates of photosynthesis of Vitis vinifera leaves decreased by $60 \%$ when temperatures increased from 25 to $45^{\circ} \mathrm{C}$. This reduction in photosynthesis was attributed to $15-30 \%$ stomatal closure. The photosynthetic rate is also determined by the capacity of carboxylation of Rubisco, which is highly dependent on temperature. Elevated temperatures decrease the state of activation of Rubisco due to the inactivation of the Rubisco activase enzyme, thereby affecting the carbamylation process of the Rubisco [63-66]. When Rubisco acts as carboxylase, products are frequently formed that prevent its activation, and these should be eliminated from the active site by the Rubisco activase [67,68]. Rubisco activase is relatively labile to heat $[65,69]$; therefore, its capacity to maintain the Rubisco's state of activation is expected to decrease with elevated temperatures. Plants expressing a more thermotolerant Rubisco activase have higher net photosynthesis at elevated temperatures [70,71]. On the other hand, as the temperature increases, the rate of photosynthesis decreases, with the rate of photorespiration increasing more rapidly [72]. There are two reasons for this. First, as temperatures increase, Rubisco's affinity for $\mathrm{CO}_{2}$ decreases compared with that of the $\mathrm{O}_{2}$. Thus, the oxygenation reaction of the Rubisco is more frequent $[73,74]$. Second, as the temperature increases, the $\mathrm{O}_{2}$ solubility decreases more slowly than the $\mathrm{CO}_{2}$ solubility [75]. Therefore, in warm environments, there is relatively more $\mathrm{O}_{2}$ available to react with the Rubisco.

The clearest evidence that elevated $\mathrm{CO}_{2}$ and elevated temperatures will alter plant carbon fluxes comes from studies that manipulate both factors $[46,76]$. These data imply that the plant carbon flux response to temperature varies across species. Lee et al. [31] observed that the concurrent elevation of temperature and $\mathrm{CO}_{2}$ enhanced plant thermostability and reduced the damaging effect of elevated temperatures in potato plants.

\section{Elevated $\mathrm{CO}_{2}$ Levels and Elevated Temperatures on Nitrogen Metabolism in Sunflower Plants}

Nitrogen is the mineral with the greatest impact in terms of limiting the primary growth and productivity of plants in natural systems and in agriculture. In most soils, nitrogen tends to appear in the form of nitrate $\left(\mathrm{NO}_{3}{ }^{-}\right)$, since ammonium $\left(\mathrm{NH}_{4}{ }^{+}\right)$, including that which is added to the soil as fertilizer, is rapidly oxidized to $\mathrm{NO}_{3}{ }^{-}$by nitrifying bacteria. In plants, nitric nitrogen converts into ammonium nitrogen, a process known as assimilatory reduction in $\mathrm{NO}_{3}$. The assimilation of $\mathrm{NO}_{3}{ }^{-}$is regulated by endogenous and/or exogenous factors, such as $\mathrm{NO}_{3}{ }^{-}$, carbon compounds, and light. $\mathrm{NH}_{4}{ }^{+}$produced from the assimilatory reduction in $\mathrm{NO}_{3}{ }^{-}$, combined with that resulting from other metabolic 
reactions, is added to the carbon compounds to synthesize nitrogenated compounds that the plant uses for its growth [77].

Stitt and Krapp [78] initially assumed that some plant species required a higher rate of $\mathrm{NO}_{3}{ }^{-}$assimilation to permit increased plant growth under conditions of elevated $\mathrm{CO}_{2}$ concentrations. However, it was found that $\mathrm{CO}_{2}$ enrichment inhibits the assimilation of $\mathrm{NO}_{3}{ }^{-}$in sunflowers [79] as well as in wheat plants, Arabidopsis [80], and field-grown wheat [45]. The assimilation of $\mathrm{NO}_{3}{ }^{-}$requires the reduced form of nicotinamide adenine dinucleotide (NADH) in order for the nitrate reductase (NR) to catalyze the formation of $\mathrm{NO}_{2}{ }^{-}$based on $\mathrm{NO}_{3}{ }^{-}$. Photorespiration stimulates the release of malate from the chloroplasts and increases the availability of $\mathrm{NADH}$ in the cytosol, thereby increasing the $\mathrm{NR}$ activity [81], which permits the first step in $\mathrm{NO}_{3}{ }^{-}$assimilation [82]. Elevated $\mathrm{CO}_{2}$ concentrations reduce photorespiration and thus, decrease the quantity of NADH available for the reduction in $\mathrm{NO}_{3}{ }^{-}$. This may explain the decreased levels of NR activity observed in sunflower plants under conditions of elevated $\mathrm{CO}_{2}$ [79]. However, six transporters from the Nar1 family are involved in the translocation of $\mathrm{NO}_{2}{ }^{-}$from the cytosol to the chloroplast in Chlamydomonas some of these transport both $\mathrm{NO}_{2}{ }^{-}$as well as $\mathrm{HCO}_{3}{ }^{-}$[83]. Bloom et al. [84] revealed that $\mathrm{HCO}_{3}{ }^{-}$inhibits the entry of $\mathrm{NO}_{2}{ }^{-}$in isolated chloroplasts of wheat and peas, indicating that an analogous system is operating in higher plants. Therefore, a decrease in the affluence of $\mathrm{NO}_{2}{ }^{-}$to the chloroplast may result from higher $\mathrm{CO}_{2}$ levels, which may also explain the reduced glutamine synthetase (GS) activity observed in sunflower plants grown under enriched $\mathrm{CO}_{2}$ conditions [79]. Studies have shown that both chloroplast isoforms and GS cytosols are affected by abiotic stress [85]. De la Mata et al. [79] observed that an elevated $\mathrm{CO}_{2}$ level significantly increased the relative expression of the GS1 isoform (cytosol), but decreased the GS2 transcription levels (chloroplast) in sunflower leaves. Recently, a high correlation was reported between increases in carbohydrate content and the downregulation of genes involved in photosynthesis and $\mathrm{N}$ metabolism [86].

In sunflower plants grown at elevated $\mathrm{CO}_{2}$ levels $(800 \mu \mathrm{L} \mathrm{L})$ and elevated nitrate availability $(25 \mathrm{mM})$, the primary leaves reveal an increased growth, photosynthetic capacity, assimilation of nitrogen, and antioxidant defenses compared with plants grown at elevated $\mathrm{CO}_{2}$ levels and limited nitrogen. This results in a delay in the leaf's senescence process, demonstrating that the induction of the senescence process is directly related to the $\mathrm{C} / \mathrm{N}$ ratio of the leaf [87]. This $\mathrm{C} / \mathrm{N}$ ratio should be balanced in order for the plant to be more productive. An elevated $\mathrm{CO}_{2}$ increases this ratio in plants due to the decrease in nitrogen content in the leaf [79]. Sunflower plants that are biofertilized via inoculation with mycorrhizal fungi (Rhizophagus irregularis) and are grown in environments of elevated $\mathrm{CO}_{2}$, and reveal a decrease in the $\mathrm{C} / \mathrm{N}$ ratio compared with plants grown at elevated $\mathrm{CO}_{2}$ levels and without biofertilizers. These results suggest that sunflower symbiosis with $R$. irregularis improves the absorption of nitrogen favoring the stability of the $\mathrm{C} / \mathrm{N}$ ratio in the plant, despite the elevated atmospheric $\mathrm{CO}_{2}$ levels [88]. De la Haba et al. [27] observed in primary leaves of sunflower plants that the NR and GS activity decreased while decreased activity in glutamate dehydrogenase increased in leaves exposed to elevated temperature. A superior decrease in the soluble protein content during leaf life span in plants grown at elevated temperatures suggests that elevated temperatures promote soluble protein degradation in sunflower leaf.

Although elevated $\mathrm{CO}_{2}$ concentrations and temperatures have been treated separately, in terms of the reduced availability of nitrogen in plants, especially sunflowers $[16,18]$, there are little data on the combined effect of these factors. More research is necessary before any broad-scale conclusions can be made with regard to the interaction between elevated $\mathrm{CO}_{2}$ and elevated temperature.

\section{Oxidative Stress in Sunflower Plants to Elevated $\mathrm{CO}_{2}$ and Temperature}

Elevated levels of $\mathrm{CO}_{2}$ decreased the content of photosynthetic pigments (chlorophyll $a$ and $b$ and carotenoids) and increased the oxidative stress on the sunflower plants, by increasing $\mathrm{H}_{2} \mathrm{O}_{2}$ levels and decreasing the activity of antioxidant enzymes, such as catalase 
and ascorbate peroxidase [25]. The loss of antioxidant defenses in the plant probably increases the concentration of the reactive species of oxygen in the chloroplast, thereby decreasing the content of photosynthetic pigments [25]. Biofertilization through fungi (Rhizophagus irregularis) in sunflower plants grown in environments of high $\mathrm{CO}_{2}$ reveals a decreased hydrogen peroxide content and increased antioxidant enzyme activity (catalase and APX). These results suggest that sunflower symbiosis with $R$. irregularis decreases the plant's oxidative stress [88]. Seemingly, an increase in antioxidant defenses is a mechanism that can be used to mitigate the effect of $\mathrm{CO}_{2}$ on plants [89]. A better understanding of these processes during leaf development is essential to improving crop productivity in a $\mathrm{CO}_{2}$-rich atmosphere. It has also been observed that elevated temperatures decrease activity levels of antioxidant enzymes [90] and induce oxidative stress in plants since reactive oxygen species (ROSs) are produced, for example, superoxide radicals $\left(\mathrm{O}_{2}-\right), \mathrm{H}_{2} \mathrm{O}_{2}$, and hydroxyl radicals (HO) [91]. The accumulation of ROS not only has negative consequences on cells but also acts on the stress signaling pathways, activating the synthesis of thermal shock protein transcription factors [92]. It was suggested that, similar to other types of abiotic stress, stress caused by heat may decouple enzymes and metabolic channels that cause an accumulation of ROSs, which are responsible for oxidative stress [93]. In sunflower plants grown at elevated temperatures, considerable oxidative stress was found during leaf development, as revealed by the significant increase in $\mathrm{H}_{2} \mathrm{O}_{2}$ and the clear decrease in antioxidant enzyme activity (CAT and APX) compared with plants grown at control temperatures [27]. An increased expression of CAT and APX at elevated temperatures in heat-tolerant sugar cane leaf genotypes may protect from ROSs and $\mathrm{H}_{2} \mathrm{O}_{2}$, superoxide and hydroxyl radicals caused by plants exposed to high temperatures [94]. Elevated temperatures decrease the growth of 42-day-old sunflower primary leaves, negatively affecting markers that are commonly used to monitor leaf development and increasing oxidative state 42-day-old sunflower primary leaves [95].

It has recently been observed that the protein profiles examined in sunflower leaves revealed marked differences in protein expression between plants grown under the two temperature conditions (low and elevated temperatures). Interestingly, $26.4 \%$ of the identified proteins, mainly categorized in four functional groups (1-antioxidant, 2-stress and defense, 3-energy and metabolism-related, and 4-hormonal regulation proteins), exhibited increased expression in response to higher growth temperatures. These molecular differences detected in primary leaves at elevated temperatures can indicate a greater tolerance of sunflower plants to these stress conditions [95].

\section{Conclusions}

Within the context of current environmental conditions and those projected for the coming decades, an urgent need exists to increase crop performance by developing crops that are resistant to environmental changes. We believe that deepening our understanding of the combined effects of increased temperatures and $\mathrm{CO}_{2}$ concentrations on the development of sunflower plants is essential to predict the impact of climate change because the sunflower is an important oil crop worldwide. Therefore, we advocate the expansion of studies in sunflower plants, combining elevated $\mathrm{CO}_{2}$ and elevated temperature to provide the information required to guide strategies that provide plant improvement in a future climate. Emphasizing the need to address the responses of growth, carbon and nitrogen metabolism, as well as the oxidative state of the plant to climate change, will provide comprehensive information and open new pathways to mitigate and adapt to the impacts of increased $\mathrm{CO}_{2}$ and temperatures in vegetation.

Figure 2 shows a summary of the modifications taking place in sunflower plants when grown to elevated $\mathrm{CO}_{2}$ levels and temperatures independently, a result of the different investigations carried out by our group on sunflowers. 


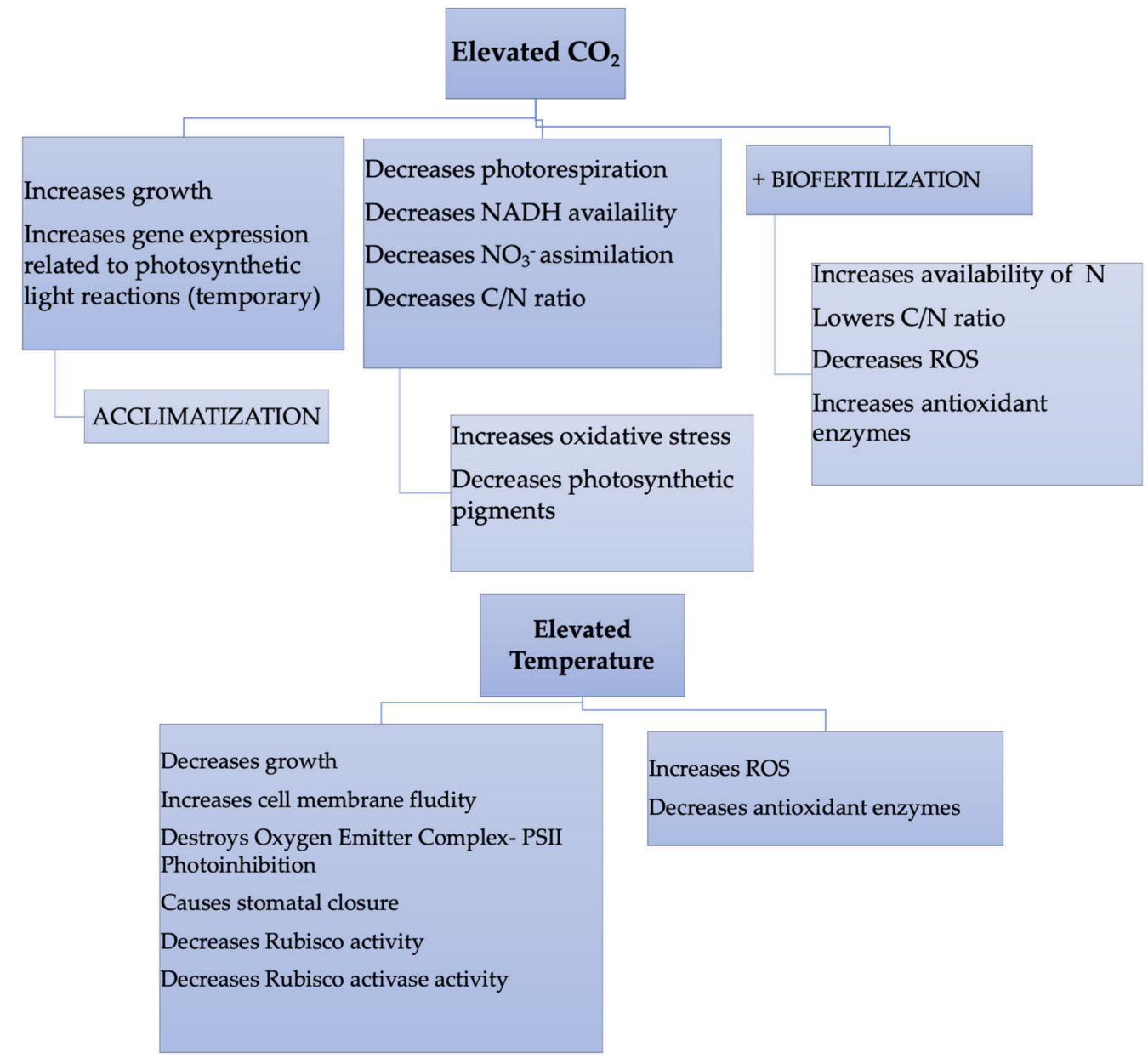

Figure 2. Modifications in sunflower plants due to the increase in $\mathrm{CO}_{2}$ and environmental temperatures.

Author Contributions: Conceptualization, E.A.; Investigation, P.d.1.H. and E.A.; Resources, P.d.1.H. and E.A.; Supervision, P.d.l.H. and E.A.; Funding acquisition E.A. and P.d.1.H. All authors have read and agreed to the published version of the manuscript.

Funding: This research was funded by grateful to the University of Córdoba Programa Propio (XXPP.MO 4.1) and Junta de Andalucía PAI Group BIO-159.

Data Availability Statement: Not applicable.

Conflicts of Interest: The authors declare no conflict of interest.

\section{References}

1. NASA Global Climate Change. Vital Sings of Planet. 2019. Available online: http://climate.nasa.gov.vitals-signs/carbon-dioxide (accessed on 8 September 2021).

2. IPCC. Intergovernmental panel on climate change 2014: Impacts, adaptations and vulnerability. In Contribution of Working Group II to the Fifth Assessment. Report of the Intergovernmental Panel on Climate Change; Field, C.B., Barros, V.R., Dokken, D.J., Mach, K.J., Eds.; Cambridge University Press: Ginebra, UK, 2014.

3. Schneider, S.H. The greenhouse effect: Science and policy. Science 1989, 243, 771-781. [CrossRef]

4. Taylor, K.E.; MacCracken, M.C. Projected effects of increasing concentrations of carbon dioxide and trace gases on climate. In Impact of Carbon Dioxide, Trace Gases, and Climate Change on Global Agriculture; Kimball, B.A., Ed.; American Society of Agronomy, Crop Science Society of America, and Soil Science Society of America: Madison, WI, USA, 1990; pp. 1-17.

5. Templer, P.H.; Pinder, R.W.; Goodale, C.L. Effects of nitrogen deposition on greenhouse-gas fluxes for forests and grasslands of North America. Front. Ecol. Environ. 2012, 10, 547-553. [CrossRef]

6. Fukayama, H.; Sugino, M.; Fukuda, T.; Masumoto, C.; Taniguchi, Y.; Okada, M.; Sameshima, R.; Hatanaka, T.; Misoo, S.; Hasegawa, T.; et al. Gene expression profiling of rice grown in free air $\mathrm{CO}_{2}$ enrichment (FACE) and elevated soil temperature. Field Crops Res. 2011, 121, 195-199. [CrossRef] 
7. Gruissem, W.; Lee, C.; Oliver, M.; Pogson, B. The global plant council: Increasing the impact of plant research to meet global challenges. J. Plant Biol. 2012, 55, 343-345. [CrossRef]

8. Maas, E.V.; Hoffman, G.J. Crop salt tolerance, current assessment. J. Irrig. Drain Div. ASCE 1977, 103, 115-134. [CrossRef]

9. Kratsch, H.A.; Wise, R.R. The ultrastructure of chilling stress. Plant Cell Environ. 2000, 23, 337-350. [CrossRef]

10. Huang, L.; Ye, Z.; Bell, R.W.; Dell, B. Boron nutrition and chilling tolerance of warm climate crop species. Ann. Bot. 2005, 96, 755-767. [CrossRef] [PubMed]

11. Connor, D.J.; Palta, J.A.; Jones, T.R. Response of sunflower to strategies of irrigation. III. Crop photosynthesis and transpiration. Field Crop Res. 1985, 12, 281-283. [CrossRef]

12. Connor, D.J.; Jones, T.R. Response of sunflower to strategies of irrigation II. Morphological and physiological responses to water stress. Field Crop Res. 1985, 12, 91-103. [CrossRef]

13. Sadras, V.O.; Whitfield, D.M.; Connor, D.J. Regulation of evapotranspiration and its partitioning between transpiration and soil evaporation by sunflower crops. A comparison between hybrids of different stature. Field Crop Res. 1991, 28, 17-37. [CrossRef]

14. Moschen, S.; Di Rienzo, J.A.; Higgins, J.; Tohge, T.; Watanabe, M.; González, S.; Rivarola, M.; García-García, F.; Dopazo, J.; Hopp, H.E.; et al. Integration of transcriptomic and metabolic data reveals hub transcription factors involved in drought stress response in sunflower (Helianthus annuus L.). Plant Mol. Biol. 2017, 94, 549-564. [CrossRef]

15. Nishimura, C.; Ohashi, Y.; Sato, S.; Kato, T.; Tabata, S.; Ueguchi, C. Histidine kinase homologs that act as cytokinin receptors possess overlapping functions in the regulation of shoot and root growth in Arabidopsis. Plant Cell 2004, 16, 1365-1377. [CrossRef]

16. Tsukaya, H. Mechanism of leaf-shape determination. Annu. Rev. Plant Biol. 2006, 57, 477-496. [CrossRef]

17. Riikonen, J.; Percy, K.E.; Kivimäenpää, M.; Kubiske, M.E.; Nelson, N.D.; Vapaavuori, E.; Karnosky, D.F. Leaf size and surface characteristics of Betula papyrifera exposed to elevated $\mathrm{CO}_{2}$ and $\mathrm{O}_{3}$. Environ. Pollut. 2010, 158, 1029-1035. [CrossRef]

18. Ranasinghe, S.; Taylor, G. Mechanism for increased leaf grwoth in elevated $\mathrm{CO}_{2}$. J. Exp. Bot. 1996, 47, 349-358. [CrossRef]

19. Kinsman, E.; Lew, D.M.; Young, J.F.D.; Vilhar, B.; Ougham, H. Elevated $\mathrm{CO}_{2}$ stimulates cells to divide in grass meristems: A differential effect in two natural populations of Dactylis glomerata. Plant Cell Environ. 1997, 20, 1309-1316. [CrossRef]

20. Ferris, R.; Sabatti, M.; Miglietta, F.; Mills, R.; Taylor, G. Leaf area is stimulated in Populus by free air $\mathrm{CO}_{2}$ enrichment (POPFACE), through increased cell expansion and production. Plant Cell Environ. 2001, 24, 305-315. [CrossRef]

21. Ainsworth, E.A.; Rogers, A.; Vodkin, L.O.; Walter, A.; Schurr, U. The effects of elevated $\mathrm{CO}_{2}$ concentration on soybean gene expression. An analysis of growing and mature leaves. Plant Physiol. 2006, 142, 135-147. [CrossRef] [PubMed]

22. Kontunen-Soppela, S.; Parviainen, J.; Ruhanen, H.; Brosche, M.; Keinänen, M.; Thakur, R.C.; Kolehmainen, M.; Kangasjärvi, J.; Oksanen, E.; Karnosky, D.F. Gene expression responses of paper birch (Betula papyrifera) to elevated $\mathrm{CO}_{2}$ and $\mathrm{O}_{3}$ during leaf maturation and senescence. Environ. Pollut. 2010, 158, 959-968. [CrossRef]

23. Wei, H.; Gou, J.; Yordanov, Y.; Zhang, H.; Thakur, R.; Jones, W.; Burton, A. Global transcriptomic profiling of aspen trees under elevated $\left[\mathrm{CO}_{2}\right]$ to identify potential molecular mechanisms responsible for enhanced radial growth. J. Plant Res. 2013, 126, 305-320. [CrossRef] [PubMed]

24. Thilakarathne, C.L.; Tausz-Posch, S.; Cane, K.; Norton, R.M.; Fitzgerald, G.J.; Tausz, M.; Seneweera, S. Intraspecific variation in leaf growth of wheat (Triticum aestivum) under Australian Grain Free $\mathrm{CO}_{2}$ Enrichment (AGFACE): Is it regulated through carbon and/or nitrogen supply? Func. Plant Biol. 2015, 42, 299-308. [CrossRef]

25. De la Mata, L.; Cabello, P.; de la Haba, P.; Agüera, E. Growth under elevated atmospheric $\mathrm{CO}_{2}$ concentration accelerates leaf senescence in sunflower (Helianthus annuus L.) plants. J. Plant Physiol. 2012, 169, 1392-1400. [CrossRef] [PubMed]

26. Gamage, D.; Thompson, M.; Sutherland, M.; Hirotsu, N.; Makino, A.; Seneweera, S. New insights into the cellular mechanisms of plant growth at elevated atmospheric carbon dioxide concentrations. Plant Cell Environ. 2018, 41, 1233-1246. [CrossRef] [PubMed]

27. De la Haba, P.; De la Mata, L.; Molina, E.; Aguera, E. High temperature promotes early senescence in primary leaves of sunflower (Helianthus annuus L.) plants. Can. J. Plant Sci. 2014, 94, 659-669. [CrossRef]

28. Ferguson, D.L.; Guikema, J.A.; Paulsen, G.M. Ubiquitin pool modulation and protein degradation in wheat roots during high temperature stress. Plant Physiol. 1990, 92, 740-746. [CrossRef]

29. Scheurwater, I.; Dunnebacke, M.; Eising, R.; Lambers, H. Respiratory costs and rate of protein turnover in the roots of a fast-growing (Dactylis glomerata L.) and a slow-growing (Festuca ovina L.) grass species. J. Exp. Bot. 2000, 51, 1089-1097. [PubMed]

30. Benlloch-González, M.; Bochicchio, R.; Berger, J.D.; Bramley, H.; Palta, J. High temperature reduces the positive effect of elevated $\mathrm{CO}_{2}$ on wheat root system growt. Fields Crops Res. 2014, 165, 71-79. [CrossRef]

31. Lee, I.H.; Sang, W.G.; Baek, J.-K.; Kim, J.-H.; Shin, P.; Seo, M.C.; Cho, J.I. The effect of concurrent elevation in $\mathrm{CO}_{2}$ and temperature on the growth, photosynthesis, and yield of potato crops. PLoS ONE 2020, 15, e0241081.

32. Awais, M.; Wajid, A.; Saleem, M.F.; Nasim, W.; Ahmad, A.; Raza, M.A.S.; Bashir, M.U.; Mubeen, M.; Hammad, H.M.; Rahman, M.H.; et al. Potential impacts of climate change and adaptation strategies for sunflower in Pakistan. Environ. Sci. Poll Res. 2018, 25, 13719-13730. [CrossRef]

33. Liu, M.; Xua, X.; Jiang, Y.; Huang, Q.; Huo, Z.; Liu, L.; Huang, G. Responses of crop growth and water productivity to climate change and agricultural water-saving in arid region. Sci. Total Environ. 2020, 703, 134621. [CrossRef]

34. Nowicka, B.; Ciura, J.; Szymanska, R.; Kruk, J. Improving photosynthesis, plant productivity and abiotic stress tolerance current trends and future perspectives. J. Plant Physiol. 2018, 231, 415-433. [CrossRef]

35. Drake, B.G.; Gonzàlez-Meler, M.A.; Long, S.P. More efficient plants: A consequence of rising atmospheric $\mathrm{CO}_{2}$ ? Annu. Rev. Plant Physiol. Plant Mol. Biol. 1997, 48, 609-639. [CrossRef] 
36. Pritchard, S.G.; Ju, Z.; van Santen, E.; Qiu, J.; Weaver, D.B.; Prior, S.A.; Rogers, H.H. The influence of elevated $\mathrm{CO}_{2}$ on the activities of antioxidative enzymes in two soybean genotypes. Aust. J. Plant Physiol. 2000, 27, 1061-1068. [CrossRef]

37. Bauwe, H.; Hagemann, M.; Fernie, A.R. Photorespiration: Players, partners and origin. Trends Plant Sci. 2010, 15, 330-336. [CrossRef] [PubMed]

38. Van Heerden, P.; Swanepoel, J.; Kruger, G. Modulation of photosynthesis by drought in two desert scrub species exhibiting C 3-mode $\mathrm{CO}_{2}$ assimilation. Environ. Ex Bot. 2007, 61, 124-136. [CrossRef]

39. Zhang, D.-Y.; Chen, G.-Y.; Gong, Z.-Y.; Chen, J.; Yong, Z.-H.; Zhu, J.-G.; Xu, D.-Q. Ribulose-1, 5-bisphosphate regeneration limitation in rice leaf photosynthetic acclimation to elevated $\mathrm{CO}_{2}$. Plant Sci. 2008, 175, 348-355. [CrossRef]

40. Sekhar, K.M.; Sreeharsha, R.V.; Reddy, A.R. Differential responses in photosynthesis, growth and biomass yields in two mulberry genotypes grown under elevated $\mathrm{CO}_{2}$ atmosphere. J. Photochem. Photobiol. B Biol. 2015, 151, 172-179. [CrossRef] [PubMed]

41. Vicente, R.; Pérez, P.; Martínez-Carrasco, R.; Usadel, B.; Kostadinova, S.; Morcuende, R. Quantitative RT-PCR platform to measure transcript levels of $\mathrm{C}$ and $\mathrm{N}$ metabolism-related genes in durum wheat: Transcript profiles in elevated $\left[\mathrm{CO}_{2}\right]$ and high temperature at different levels of N supply. Plant Cell Physiol. 2015, 56, 1556-1573. [CrossRef]

42. Kant, S.; Seneweera, S.; Rodin, J.; Materne, M.; Burch, D.; Rothstein, S.J.; Spangenberg, G. Improving yield potential in crops under elevated $\mathrm{CO}_{2}$ : Integrating the photosynthetic and nitrogen utilization efficiencies. Front. Plant Sci. 2012, 3, 162. [CrossRef]

43. Long, S.P.; Ainsworth, E.A.; Rogers, A.; Ort, D.R. Rising atmospheric carbon dioxide: Plants FACE the future. Annu. Rev. Plant Biol. 2004, 55, 591-628. [CrossRef]

44. Kitaoka, S.; Matsuki, S.; Kitao, M.; Tobita, H.; Utsugi, H.; Maruyama, Y.; Koike, T. The photosynthetic response of four seral deciduous broad-leaved tree seedlings grown under elevated $\mathrm{CO}_{2}$ concentrations. J. Agric. Meteorol. 2016, 72, 3-49. [CrossRef]

45. Bloom, A.J.; Burger, M.; Kimball, B.A.; Pinter, P.J. Nitrate assimilation is inhibited by elevated $\mathrm{CO}_{2}$ in field-grown wheat. Nat. Clim. Chang. 2014, 4, 477-480. [CrossRef]

46. Ruiz-Vera, U.M.; De Souza, A.P.; Long, S.P.; Ort, D.R. The role of sink strength and nitrogen availability in the down-regulation of photosynthetic capacity in field-grown Nicotiana tabacum L. at elevated $\mathrm{CO}_{2}$ concentration. Front. Plant Sci. 2017, 8, 998. [CrossRef] [PubMed]

47. Bahrami, H.; De Kok, L.J.; Armstrong, R.; Fitzgerald, G.J.; Bourgault, M.; Henty, S.; Tausz, M.; Tausz-Posch, S. The proportion of nitrate in leaf nitrogen, but not changes in root growth, are associated with decreased grain protein in wheat under elevated $\left[\mathrm{CO}_{2}\right]$. J. Plant. Physiol. 2017, 216, 44-51. [CrossRef]

48. Riikonen, J.; Kets, K.; Darbah, J.; Oksanen, E.; Sober, A.; Vapaavuori, E.; Kubiske, M.E.; Nelson, N.; Karnosky, D.F. Carbon gain and bud physiology in Populus tremuloides and Betula papyrifera grown under long-term exposure to elevated concentrations of $\mathrm{CO}_{2}$ and $\mathrm{O}_{3}$. Tree Physiol. 2008, 28, 243-254. [CrossRef]

49. Larios, B.; Agüera, E.; de la Haba, P.; Pérez-Vicente, R.; Maldonado, J.M. A short-term exposure of cucumber plants to rising atmospheric $\mathrm{CO}_{2}$ increases leaf carbohydrate content and enhances nitrate reductase expression and activity. Planta 2001, 212, 305-312. [CrossRef]

50. Agüera, E.; Ruano, D.; Cabello, P.; De la Haba, P. Impact of atmospheric $\mathrm{CO}_{2}$ on growth, photosynthesis and nitrogen metabolism in cucumber (Cucumis sativus L.) plants. J. Plant Physiol. 2006, 163, 809-817. [CrossRef]

51. Ainsworth, E.A.; Long, S.P. What have we learned from 15 years of free-air $\mathrm{CO}_{2}$ enrichment (FACE)? A meta-analytic review of the responses of photosynthesis, canopy properties and plant production to rising $\mathrm{CO}_{2}$. New Phytol. 2005, 165, 351-372. [CrossRef]

52. Bae, H.; Sicher, R. Changes of soluble protein expression and leaf metabolite levels in Arabidopsis thaliana grown in elevated atmospheric carbon dioxide. Field Crop Res. 2004, 90, 61-73. [CrossRef]

53. Araya, T.; Noguchi, K.; Terashima, I. Differences between sink and source leaves in carbohydrate repression of photosynthesis. In Photosynthesis: Fundamental Aspects to Global Perspective; van der Est, A., Bruce, D., Eds.; International Society of Photosynthesis: Monterreal, QC, Canada, 2005; pp. 660-662.

54. Gray, S.B.; Brady, S.M. Plant developmental responses to climate change. Develop. Biol. 2016, 419, 64-77. [CrossRef] [PubMed]

55. Arcus, V.L.; Prentice, E.J.; Hobbs, J.K.; Mulholland, A.J.; Van der Kamp, M.W.; Pudney, C.R.; Parker, E.J.; Schipper, L.A. On the temperature dependence of enzyme catalyzed rates. Biochemistry 2016, 55, 1681-1688. [CrossRef]

56. Li, Q.; Zheng, Q.; Shen, W.; Cram, D.; Fowler, D.B.; Wei, Y.; Zou, J. Understanding the biochemical basis of temperature-induced lipid pathway adjustments in plants. Plant Cell. 2015, 27, 86-103. [CrossRef] [PubMed]

57. Semenova, G. Structural reorganization of thylakoid systems in response to heat treatment. Photosynthetica 2004, 42, 521-527. [CrossRef]

58. Aro, E.; Virgin, I.; Andersson, B. Photoinhibition of photosystem II. Inactivation, protein damage and turnover. Biochim. Biophys. Acta 1993, 1143, 113-134. [CrossRef]

59. Murata, N.; Takahashi, S.; Nishiyama, Y.; Allakhverdiev, S.I. Photoinhibition of photosystem II under environmental stress Biochim. Biophys. Acta 2007, 1767, 414-421. [CrossRef] [PubMed]

60. Takahashi, S.; Murata, N. How do environmental stresses accelerate photoinhibition? Trends Plant Sci. 2008, 13, 178-182. [CrossRef] [PubMed]

61. Greer, D.H.; Weedon, M.M. Modelling photosynthetic responses to temperature of grapevine (Vitis vinifera cv. Semillon) leaves on vines grown in a hot climate. Plant Cell Environ. 2012, 35, 1050-1064. [CrossRef] [PubMed] 
62. Greer, D.H.; Weston, C. Heat stress affects flowering, berry growth, sugar accumulation and photosynthesis of Vitis vinifera cv. Semillon grapevines grown in a controlled environment. Func. Plant Biol. 2010, 37, 206-214. [CrossRef]

63. Feller, U.; Crafts-Brandner, S.J.; Salvucci, M.E. Moderately high temperatures inhibit ribulose-1,5-bisphosphate carboxylase/oxygenase (rubisco) activase-mediated activation of rubisco. Plant Physiol. 1998, 116, 539-546. [CrossRef]

64. Jiang, D.; Lu, Q.; Weng, X.; Zheng, B.; Xi, H. Regulation of rubisco carboxylation activity and photosynthetic rate by rubisco activase during leaf senescence in rice. J. Zhejiang Univ. (Agricult. Life Sci.) 1999, 26, 119-124.

65. Salvucci, M.E.; Crafts-Brandner, S.J. Inhibition of photosynthesis by heat stress: The activation state of rubisco as a limiting factor in photosynthesis. Physiol. Plant 2004, 120, 179-186. [CrossRef]

66. Demirevska-Kepova, K.; Holzer, R.; Simova-Stoilova, L.; Feller, U. Heat stress effects on ribulose-1, 5-bisphosphate carboxylase/oxygenase, rubisco binding protein and rubisco activase in wheat leaves. Biol. Plant. 2005, 49, 521-525. [CrossRef]

67. Carmo-Silva, E.; Scales, J.C.; Madgwick, P.J.; Parry, M.A.J. Optimizing Rubisco and its regulation for greater resource use efficiency. Plant Cell Environ. 2015, 38, 1817-1832. [CrossRef] [PubMed]

68. Bracher, A.; Whitney, S.M.; Hartl, F.U.; Hayer-Hartl, M. Biogenesis and metabolic maintenance of Rubisco. Annu. Rev. Plant Biol. 2017, 68, 29-60. [CrossRef]

69. Crafts-Brandner, S.J.; Salvucci, M.E. Sensitivity of photosynthesis in a C4 plant, maize, to heat stress. Plant Physiol. 2002, 129, 1773-1780. [CrossRef]

70. Itzhak Kurek, O.; Kai Chang, T.; Bertain, S.M.; Madrigal, A.; Liu, L.; Lassner, M.W.; Zhu, G. Enhanced thermostability of Arabidopsis Rubisco activase improves photosynthesis and growth rates under moderate heat stress. Plant Cell 2007, 19, $230-3241$.

71. Kumar, A.; Verma, J.P. Does plant-microbe interaction confer stress tolerance in plants: A review? Microbiol. Res. 2018, $207,41-52$. [CrossRef]

72. Long, S.P. Modification of the response of photosynthetic productivity to rising temperature by atmospheric $\mathrm{CO}_{2}$ concentrations: Has its importance been underestimated? Plant Cell Environ. 1991, 4, 729-739. [CrossRef]

73. $\mathrm{Ku}$, S.B.; Edwards, G.E. Oxygen inhibition of photosynthesis: I. Temperature dependence and relation to $\mathrm{O}_{2} / \mathrm{CO}_{2}$ solubility ratio. Plant Physiol. 1977, 59, 986-990. [CrossRef]

74. Jordan, D.B.; Ogren, W.L. The $\mathrm{CO}_{2} / \mathrm{O}_{2}$ specificity of ribulose 1,5-bisphosphate carboxylase/oxygenase. Planta 1984, 161, 308-313. [CrossRef]

75. Ku, S.B.; Edwards, G.E. Oxygen inhibition of photosynthesis: II. Kinetic characteristics as affected by temperature. Plant Physiol. 1977, 59, 991-999. [CrossRef]

76. Dusenge, M.E.; Duarte, A.G.; Way, D.A. Plant carbon metabolism and climate change: Elevated $\mathrm{CO}_{2}$ and temperature impacts on photosynthesis, photorespiration and respiration. New Phytol. 2019, 221, 32-49. [CrossRef] [PubMed]

77. Kishorekumar, R.; Bulle, M.; Wany, A.; Gupta, K.J. An overview of important enzymes involved in nitrogen assimilation of plants. In Nitrogen Metabolism in Plants, Methods and Protocols; Gupta, K.J., Ed.; Springer Science-Business Media, LLC, Part of Springer Nature: New York, NY, USA, 2020; pp. 1-13.

78. Stitt, M.; Krapp, A. The interaction between elevated carbon dioxide and nitrogen nutrition: The physiological and molecular background. Plant Cell Environ. 1999, 22, 583-621. [CrossRef]

79. De La Mata, L.; De la Haba, P.; Alamillo, M.J.; Pineda, M.; Agüera, E. Elevated $\mathrm{CO}_{2}$ concentrations alter nitrogen metabolism and accelerate senescence in sunflower (Helianthus annuus L.) plants. Plant Soil Environ. 2013, 59, 303-308. [CrossRef]

80. Bloom, A.J.; Burger, M.; Rubio Asensio, J.S.; Cousins, A.B. Carbon dioxide enrichment inhibits nitrate assimilation in wheat and Arabidopsis. Science 2010, 328, 899-903. [CrossRef] [PubMed]

81. Igamberdiev, A.U.; Bykova, N.V.; Lea, P.J.; Gardeström, P. The role of photorespiration in redox and energy balance of photosynthetic plant cells: A study with a barley mutant deficient in glycine decarboxylase. Physiol. Plant. 2001, 111, 427-438. [CrossRef] [PubMed]

82. Quesada, A.; Gómez-García, I.; Fernández, E. Involvement of chloroplast and mitochondria redox valves in nitrate assimilation. Trends Plant Sci. 2000, 5, 463-464. [CrossRef]

83. Mariscal, V.; Moulin, P.; Orsel, M.; Miller, A.J.; Fernández, E.; Galván, A. Differential regulation of the Chlamydomonas Nar1 gene family by carbon and nitrogen. Protist 2006, 157, 421-433. [CrossRef]

84. Bloom, A.J.; Smart, D.R.; Nguyen, D.T.; Searles, P.S. Nitrogen assimilation and growth of wheat under elevated carbon dioxide. Proc. Natl. Acad. Sci. USA 2002, 99, 1730-1735. [CrossRef]

85. Bernard, S.M.; Habash, D.Z. The importance of cytosolic glutamine synthetase in nitrogen assimilation and recycling. New Phytol. 2009, 182, 608-620. [CrossRef]

86. Vicente, R.; Martínez-Carrasco, R.; Pérez, P.; Morcuende, R. New insights into the impacts of elevated $\mathrm{CO}_{2}$, nitrogen, and temperature levels on the regulation of $\mathrm{C}$ and $\mathrm{N}$ metabolism in durum wheat using network analysis. Nat. Biotechnol. 2018, 40, 192-199. [CrossRef]

87. Canales, F.J.; De la Haba, P.; Barrientos, E.; Aguera, E. Effect of $\mathrm{CO}_{2}$ enrichment and increased nitrogen supply on the induction of sunflower (Helianthus annuus L.) primary leaf senescence. Can. J. Plant. Sci. 2016, 96, 1002-1013.

88. Bellido, E.; De la Haba, P.; Aguera, E. Physiological Alteration in sunflower plants (Helianthus annuus L.) exposed to high CO 2 and arbuscular mycorrhizal fungi. Plants. 2021, 10, 937. [CrossRef] [PubMed]

89. AbdElgawad, H.; Farfan-Vignolo, E.R.; de Vos, D.; Asard, H. Elevated $\mathrm{CO}_{2}$ mitigates drought and temperature induced oxidative stress differently in grasses and legumes. Plant Sci. 2015, 231, 1-10. [CrossRef] [PubMed] 
90. Zhang, J.; Li, D.M.; Gao, Y.; Yu, B.; Xia, C.; Bai, J. Pretreatment with 5-aminolevulinic acid mitigates heat stress of cucumber leaves. Biol. Plant. 2012, 56, 780-784. [CrossRef]

91. Foyer, C.H.; Harbinson, J.; Mullineaux, P. Oxygen metabolism and the regulation of photosynthetic electron transport. In Causes of Photooxidative Stress and Amelioration of Defense Systems in Plants; Foyer, C.H., Mullineaux, P.M., Eds.; CRC Press: Boca Raton, FL, USA, 1994; pp. 1-42.

92. Dat, J.F.; Lopez-Delgado, H.; Foyer, C.; Scott, I.M. Parallel changes in $\mathrm{H}_{2} \mathrm{O}_{2}$ and catalase during thermotolerance induced by salicylic acid or heat acclimation in mustard seedlings. Plant Physiol. 1998, 116, 1351-1357. [CrossRef]

93. Xu, S.; Li, J.; Zhang, X.; Wei, H.; Cui, L. Effects of heat acclimation pretreatment on changes of membrane lipid peroxidation, antioxidant metabolites, and ultrastructure of chloroplasts in two cool-season turfgrass species under heat stress. Environ. Exp. Bot. 2006, 56, 274-285. [CrossRef]

94. Srivastava, S.; Pathak, A.D.; Gupta, P.S.; Shrivastava, A.K.; Srivastava, A.K. Hydrogen peroxide-scavenging enzymes impart tolerance to high temperature induced oxidative stress in surgarcane. Biol. J. Environ. 2012, 33, 656-661.

95. Haba, P.; Amil-Ruiz, F.; Aguera, E. Physiological and proteomic characterization of the elevated temperature effect on sunflower (Helianthus annuus L.) primary leaves. Russian J. Plant Physiol. 2020, 67, 1094-1104. [CrossRef] 